\title{
脈動を伴う二液混合微小流路内の界面構造の可視化
}

田中 利昌 ${ }^{\circ}$ (九州工業大学大学院), 速水 洋, 荒巻 森一朗 (九州大学)

永山 勝也，田中 和博 (九州工業大学)

\section{Visualization of Interface Between Oscillatory Mixing Two Liquids in a Micro Channel}

\author{
Toshimasa TANAKA, Hiroshi HAYAMI, Shinichiro ARAMAKI \\ Katsuya NAGAYAMA, Kazuhiro TANAKA
}

\begin{abstract}
An oscillatory flow was employed to improve the highly effective mixing process in a micro channel. In the present study, it is clarified on numerically and experimentally that a decrease in frequency and/or an increase in amplitude contribute to increase in the interfacial area between two liquids.
\end{abstract}

Keywords: Flow visualization, Micro channel, Oscillating flow, Mixing

\section{1. 粕 論}

近年， $\mu$-TAS（Micro Total Analysis System）に代表 される総合的な生化学分析を目指したマイクロ流体デバ イスの研究が盛んである. マイクロ化は，マクロな装置 に比べ体積当たりの界面面積が増大し，拡散距離が短く なるため，高速かつ高精度の分析を可能とする．しかし ながら，低レイノルズ数領域であり乱流混合が期待でき ないため, 微小流路内での混合は界面構造に大きく左右 されると思われる 12).

本稿では，Y字および $\mathrm{T}$ 字合流流路（以後 $\mathrm{Y}$ 字， $\mathrm{T}$ 字 と呼ぶ) を用いて，脈動の周波数および流量の制很によ って界面構造がいかに変化するかを実驗と数值計算の両 面から検証した。

\section{2. 実験方法 および 数值解析モデル}

\section{1 实験方法}

図 $1(\mathrm{a})(\mathrm{b})$ に用いた $\mathrm{Y}$ 字， $\mathrm{T}$ 字流路を示す， $\mathrm{Y}$ 字流路は ガラス板に PDMS 製流路を圧着したもので, T字流路は ガラス製で雨入口部 $200 \times$ 媣さ $100 \mu \mathrm{m}$, 合流部 $400 \times$ $100 \mu \mathrm{m}$ の矩形流路である.作動流体は水と蛍光染料 Fluorescein 水溶液(励起波長 $/$ 蛍光波長 $=490 / 520$, 濃度 200 ppm)を用い，波長 $532 \mathrm{~nm}$ のレーザー照射により営 光染料を励起させ，顕微鏡に接続した高速度カメラで撮 影し可視化画像を取得した。

シリンジポンプとチャンネルの結合は，Y 字チャンネ ルは弾性チューブで, T 字チャンネルはフレキシブルチ ューブで行っており，両方のチューブへの断続的な一定
の加堿圧（位相差 $180^{\circ}$ ）によって脈動を発生させた. 表 1 に示すCase A 〜 F の条件下で脈動の周波数と流量の 制御を行い，図 1 k示寸合流部下流 $200 \mu \mathrm{m}$ 加ら 400 $\mu \mathrm{m}$ おきに撮影項域を 5 箇所設けて, 合計 $2000 \mu \mathrm{m}$ 領 域の界面構造を可視化した．各 5 箅所は同時刻撮影では ない為定量的ではないが，定性的な検証は行えると考え る.

\section{2 数值解析モテル}

二液の界面は三次元的な広がりを持つ ${ }^{12)}$ が,その可視化 は難しく，界面拲造がどのように変化しているのか測定

Table 1 Sample of Table

\begin{tabular}{|c|c|c|c|}
\hline Type & Case & Frequency[Hz] & Q[m]/h] \\
\hline & A & 5 & 1.0 \\
& B & 10 & 1.0 \\
Y or T & C & 15 & 1.0 \\
& D & 5 & 0.5 \\
& E & 10 & 0.5 \\
& F & 15 & 0.5 \\
\hline
\end{tabular}

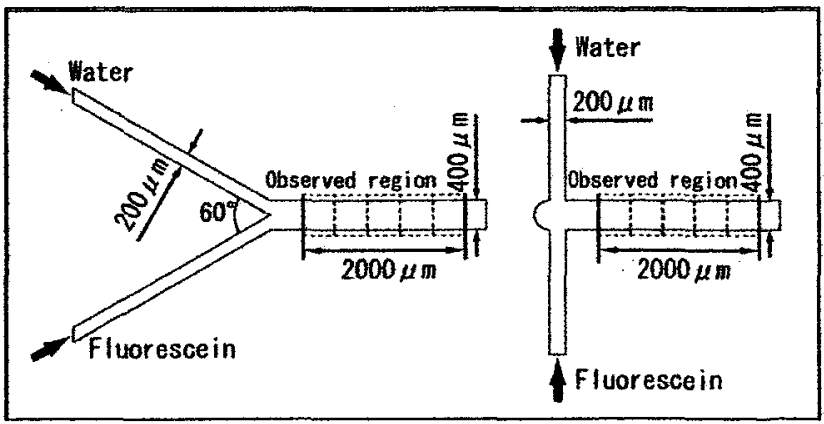

(a) Y-type

(b) T-type

Fig.1 Schematic of micro channel 
する事は非常に困難である，そこで市販の数值解析ソフ

ト Fluent6.2 を用いて解析し, FieldView8.2 を用いて可 視化表示を行った.

解析モデルの流路幅および形状は実験と同値であり， 入口部, 合流部共に長さは $6 \mathrm{~mm}$ である. 格子は構造格 子を使用し，格子間隔は最小 $10 \mu \mathrm{m}$, 計算総点数は 約 60 万点である. 流入条件は実験と同様で，実験と数 值解析結果を合わせるため, $\Delta \mathbf{Q} / \mathbf{Q}$ (脈動流量振幅/時間平 均流量) $=6$ とし 2), 時間に対して正弦波的脈動を逆位相 で与えた。境界条件は出口圧力を大気圧，タイムステッ プは周波数の $1 / 64$ とした. 作動流体は水, 片側の入口よ り染料を $0.2 \mathrm{~kg} / \mathrm{m}^{3}$ で混入し, 水と染料の拡散係数は 1.0 $\times 10^{-9} \mathrm{~m}^{2} / \mathrm{sec}$ とした.

\section{3. 実験 および 数値解析結果}

図2(a)(b)(c)に T 字流路合流管内の流路高さ中央断面で の濃度分布を示す．条件は表 1 の Case A,B,E で，全て合 流部下流 $200 \mu \mathrm{m}$ から $2000 \mu \mathrm{m}$ 領域の観測部内の画像 を表示し，白線で流路形状を，破線で境界線を示してい る(図 T 字流路 Case C,D,F，Y 字流路省略).

周波数 $5 \sim 15 \mathrm{~Hz}$ で時間平均流量 $\mathrm{Q}=1.0 \mathrm{ml}$ の場合, 界 面構造は全て縞状となり，周波数が高いほど界面の間隔 は狭くなるが, 時間平均流量 $\mathrm{Q}=0.5 \mathrm{ml}$ とし周波数を徐々 に高くすると, 界面構造は編状から波状へ変わる状態を 確認できた。

図 2 と同様に, 図 3 に(a)T 字流路(b)Y 字流路の数値解 析での濃度分布を示す. 条件は Case B,Cで, 形状の違い による流れの差異を表示したものである.

図 3 より実験と同様, 時間平均流量 $\mathrm{Q}=1.0 \mathrm{ml}$ に㧍ける 脈動周波数の増加 $(\mathrm{f}=5 \sim 15 \mathrm{~Hz})$ は, 縞状の界面間隔を徐々 に狭くする. 時間平均流量 $\mathrm{Q}=0.5 \mathrm{ml}$ においては, 縞状と 波状の界面構造の遷移状態を検証できた. また合流部で の逆流量は $\mathrm{Y}$ 字流路に比べて $\mathrm{T}$ 字流路の方が大きく, 界 面間隔も狭くなることがわかった。

したがって，界面構造は脈動周波数㧍よび脈動流量振 幅によって変化し, さらに微小流路形状もその反応・混 合の高効率化に寄与寸ることが考えられる.

今後は, さらに流路形状による混合促進の違いを詳細 に解明する必要があると思われる.

\section{4. 結 言}

異なる形状 $\mathrm{Y}$ 字, $\mathrm{T}$ 字流路を用い, 脈動の周波数と流 量の制御を行うことで二液混合の界面構造を可視化し， 以下の結論を得た。

1) 低周波数領域 $(5 \sim 15 \mathrm{~Hz})$ において時間平均流量 $(0.5$, $1.0 \mathrm{ml}$ ) を変えることによって, 界面構造の違いを 可視化することができた.

2) 微小流路形状（ $\mathrm{Y}$ 字, $\mathrm{T}$ 字流路）の違いは, 界面構 造による反応・混合の高効率化に寄与する. (a)

Case A

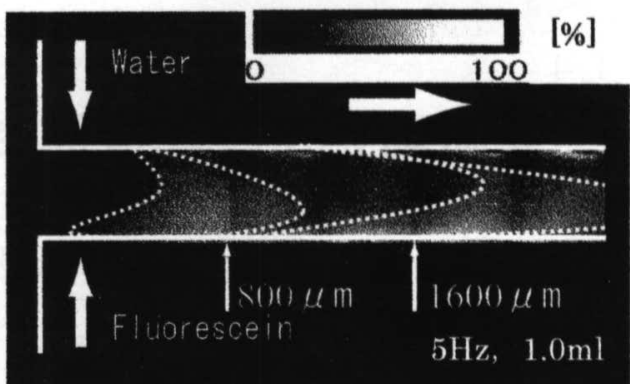

(b)

Case B

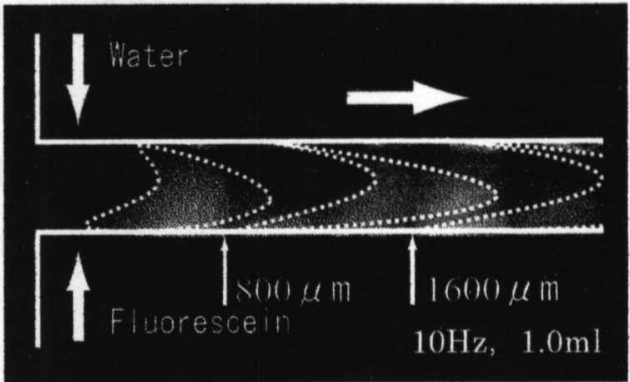

(c)

Case E

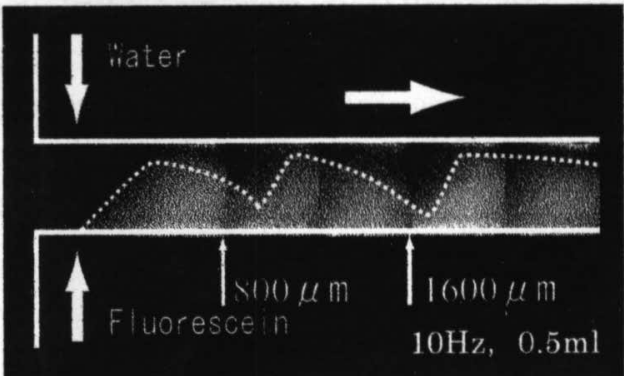

Fig.2 Oscillatory flow, experiments, phase $0^{\circ}$

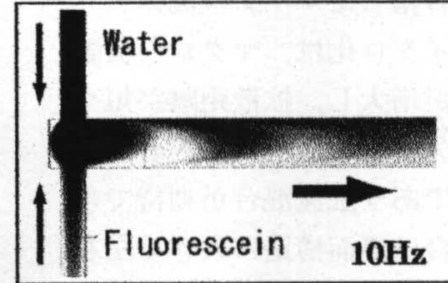

Case B

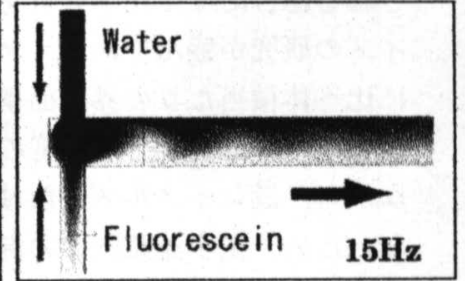

Case C (a) T-type

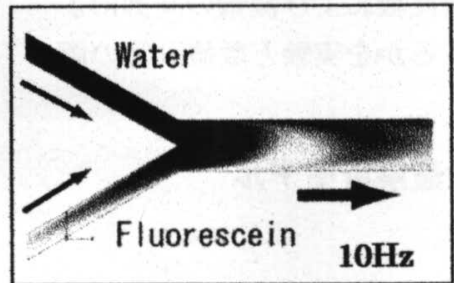

Case B

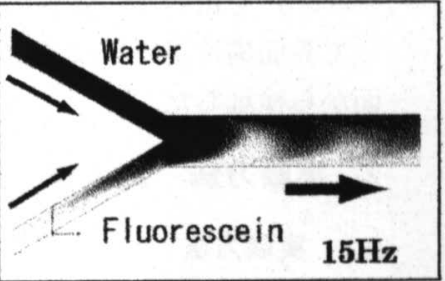

Case C (b) Y-type

Fig.3 Oscillatory flow, CFD, phase $0^{\circ}, 1.0 \mathrm{ml}$

\section{考 文 献}

1）速水 洋, 片山 健太, 荒巻 森一朗: 微小流路における 脈動流による二液混合促進, 可視化情報, Vol. 25 Suppl, No. 2 pp. 307-310, 2005

2）片山 健太, 速水 洋, 荒巻 森一朗:マイクロチャンネ ル内の混合促進を目的とした流動様式制御，可視化情報, Vol. 26 Suppl, No. 2 pp. 243-244, 2006 